\title{
A novela "Lado a Lado" e as narrativas negras sobre o passado, o presente e o futuro do Brasil
}

Resumo: O presente artigo tem como objetivo compreender as potenciais relações entre a telenovela "Lado a Lado" (Rede Globo, 2012) e o ano de 2012, tendo em vista a responsividade da telenovela como enunciado e considerando-a como uma obra de arte que se emprenha de sentidos em sua relação com a dimensão extraverbal mais ampla (VOLOCHÍNOV [BAKHTIN], 2009; BAKHTIN, 2011; VOLOCHÍNOV, 2013). Assim, em se tratando de uma telenovela de época, ambientada, na maior parte da narrativa em 1910, compreendemos em que medida a trama estabelece pontes com discursos em circulação na sociedade brasileira de 2012; e, sobretudo, ao tratar o racismo e as desigualdades raciais, produz dizeres tanto sobre os prejuízos históricos atuais da população negra brasileira, como também se refere a uma ordem social futura.

Palavras-chaves: Telenovela. Mídia e comunicação de massa. Discurso. Racismo e Desigualdade Racial.

\section{La telenovela "Lado a Lado" y las narrativas negras sobre el pasado, el presente y el futuro de Brasil}

Resumen: El presente artículo tiene como objetivo comprender las potenciales relaciones entre la telenovela "Lado a Lado" (Rede Globo, 2012) y el año de 2012, teniendo a la vista el interés de la telenovela como enunciado y teniéndola como una obra de arte que se llena de sentidos en su relación con la dimensión extra-verbal más amplia (VOLOCHÍNOV [BAKHTIN], 2009; BAKHTIN, 2011; VOLOCHÍNOV, 2013). Por consiguiente, por tratarse de una telenovela de época, ambientada, en su mayoría en 1910, comprendemos en qué medida la trama establece relaciones con discursos en circulación en la sociedad brasileña de 2012; y, sobre todo, al tratar el racismo y las desigualdades raciales, produce palabras tanto sobre perjuicios históricos actuales de la población negra brasileña, como también se refiere a un orden social futuro.

Palabras claves: Telenovela. Medios y comunicación de masa. Discurso. Racismo y Desigualdad Racial.

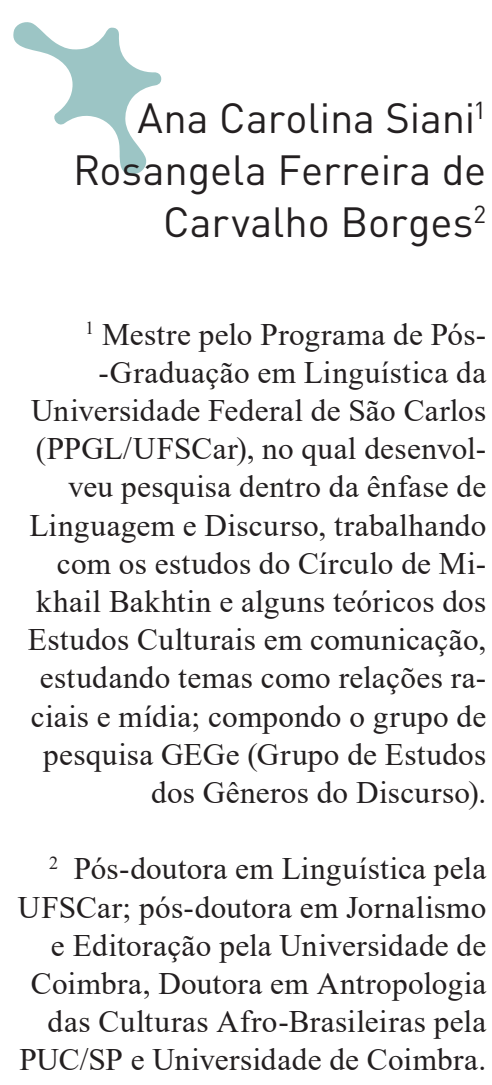




\section{The telenovela "Lado a Lado" and the black narratives about the past, the present and the future of Brazil}

\begin{abstract}
This article aims to understand the potential relationships between the telenovela "Lado a Lado" (Rede Globo, 2012) and the year 2012, in view of the telenovela's responsiveness as a statement and considering it as a work of art which is concerned with meaning in its relation to the broader extraverbal dimension (VOLOCHÍNOV [BAKHTIN], 2009; BAKHTIN, 2011; VOLOCHÍNOV, 2013). Thus, in the case of a epoch telenovela, which the narrative set in 1910, we aim to understand to what extent the plot establishes bridges with circulating discourses in brazilian society of 2012; and, above all, in dealing with racism and racial inequalities, it produces as much talk about the current historical losses of the brazilian black population as it also refers to a future social order.
\end{abstract}

Keywords: Telenovela. Media and mass communication. Speech. Racism and Racial Inequality.

\section{Vida e arte na constituição da telenovela brasileira}

Podemos considerar a telenovela como o carro-chefe da produção da indústria cultural audiovisual brasileira, consolidando-se como o maior produto de exportação dessa indústria, sendo evidente o seu reconhecimento popular, lucratividade e impacto na sociedade brasileira. A telenovela, como conhecemos hoje, estabelece-se na América Latina entre as décadas de 60 e 70, porém para pensarmos em seu funcionamento, e consolidação de seu formato enquanto gênero, há de se considerar a história e o surgimento do melodrama ${ }^{3}$ teatral.

Com sua gênese ainda no século XVIII, pode-se considerar o melodrama teatral como fruto dos espetáculos encenados ao ar livre nas feiras populares na França e Inglaterra, com os temas das narrativas vindos da literatura oral, sobretudo, dos contos de terror e mistério. Com a proibição desses teatros populares pelo governo ainda no fim do século XVII, com o objetivo de regular e impedir o alvoroço, tumultos e agitações nas ruas, passam a ser permitidas somente encenações que não fizessem uso de diálogos, nem falados ou cantados, em uma tentativa de resguardar a verdadeira arte do teatro, para que a mesma não fosse corrompida pelas classes populares (MARTÍN-BARBERO, 2009).

$\mathrm{O}$ teatro oficial, exclusivo para as classes altas e a aristocracia, e predominantemente pautado pelos grandes clássicos literários, no qual a dramaticidade se sustentava na retórica verbal, passa a se contrapor ao teatro das ruas, cujos espetáculos, agora sem direito a diálogos, se utilizavam da mímica, entre outras estratégicas cênicas, demonstrando um certo tipo de cumplicidade com o público - uso de cartazes com falas escritas, letras de canções popularmente conhecidas para o espectador cantar, etc. - e originando uma dramaticidade e encenação particular (MARTÍN-BARBERO, 2009). É
A palavra é criada na Itália, no século XVII, no âmbito da ópera italiana e referia-se a um estilo de drama cuja encenação era toda cantada (SILVA, 2013). 
interessante notar, como chama atenção Martín-Barbero (2009), que as trupes do teatro popular, além de atores, também apresentavam em sua composição acrobatas, saltimbancos, adivinhadores, etc., demonstrando a relevância da linguagem não-verbal dentro do gênero.

No bojo da Revolução Francesa, um período de intensas transformações na França, em que o público do teatro oficial passa a ser composto pelas classes populares, a partir de um decreto em 1806 que passou a autorizar a encenação de alguns espetáculos populares (MARTÍN-BARBERO, 2009), o melodrama estabelece-se como um sucesso nas salas de teatro e como um espaço privilegiado de difusão dos ideais da nova ordem social e da Revolução: "As temáticas do melodrama refletiam os ideais de 'liberdade, igualdade e fraternidade', assumindo desse modo, um papel quase institucional da Revolução" (SILVA, 2013, p. 1). Como espelho e reflexo da consciência coletiva e moralidade da Revolução, o melodrama permite que as emoções da massa popular sejam representadas e encenadas, suas paixões políticas e histórias vividas no período, os cárceres, injustiças, conspirações que acometem inocentes vítimas, heróis e justiceiros, com traidores e agressores que sofrem seus castigos no desfecho (MARTÍN-BARBERO, 2009).

Tido como gênero teatral bastardo pela crítica, o melodrama leva a tônica das mudanças sociais para o grande público:

O gênero se caracteriza em torno do bem e do mal, do oral, do excesso estético, dos juízos morais, dos jogos sentimentais, da intensificação das virtudes e vícios das personagens, sejam elas vilãs ou heróis. Ressalta determinadas características, uma vez que a finalidade desta estética é a comoção das audiências, através do verossímil, corroborando, desse modo, sua qualidade moral e sentimentalista. Sua especificidade é a utilização de música e ação melodramática, ou seja, os diálogos falados. Tais características, sobretudo a oralidade, tornam o melodrama facilmente compreensível, independentemente da referência cultural e literária do espectador, pertencente a quaisquer classes sociais, ou ainda, seja ele, culto, analfabeto ou semi-alfabetizado. (SILVA, 2013, p. 2).

Desse modo, a estética melodramática se caracteriza pela mobilização de sentimentos e emoções, por uma ótica do exagero e do excesso, além da mensagem moralizante, propagando a moral burguesa e seus valores emergentes na época, ressaltando virtudes humanas por meio de personagens mais familiares e mais próximas da vida cotidiana do público - em contraposição com as personagens das tragédias gregas do teatro tradicional de outrora, por exemplo (SILVA, 2005) - estabelecendo seu primeiro vínculo com a vida privada e doméstica, abordando conflitos familiares, caindo no gosto popular, contrapondo-se às características da educação burguesa que visava à contenção de sentimentos e emoções, que deviam ser reservados ao espaço doméstico (MARTÍN-BARBERO, 2009). Neste aspecto, é importante denotar a relação que o melodrama estabelece com a religião, consolidando-se como um substituto da compreensão religiosa sobre a vida, reconciliando virtudes civis, familiares, e fortalecendo instituições sociais, morais e religiosas (SILVA, 2013). 

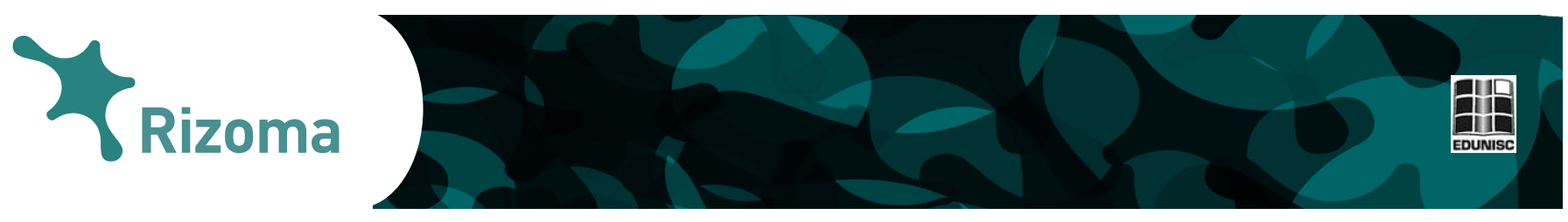

Além disso, na busca por uma verossimilhança e com o intuito de provocar emoções na plateia, se estabelece uma dinâmica entre atores e público, cujas reações funcionam como sinais para eventuais improvisos. Silva (2005) destaca os efeitos especiais:

[...] se afasta da rigidez e parcimônia do teatro clássico, apoiado fundamentalmente nas potencialidades do texto, e se volta para a ação (situações) contínua repleta de reviravoltas, o talento dos atores e a encenação enriquecida pelos efeitos especiais (incêndios, tempestades, erupções vulcânicas e até inundações, etc.), tornados possíveis pelas invenções da época engenhosamente absorvidas pelos cenógrafos e maquinistas. (SILVA, 2005, p. 53).

Podemos dizer que esse modo de narrar e estética melodramática permeia determinadas narrativas, artes dramáticas e produções culturais e artísticas até os dias atuais, senão as peças teatrais e como sugere Silva (2005) na constituição da telenovela estariam presentes gêneros como o romance folhetim, a radionovela, fotonovela, histórias em quadrinhos, fita-em-série norte-americana, etc. Uma vez tendo sido apropriada e assimilada por outros sistemas técnicos, trata-se de uma fórmula que se repete e se ritualiza, e é reelaborada, como podemos entender na telenovela como conhecemos hoje.

Já a televisão como meio de comunicação de massa com alcance nacional se estabelece no Brasil em meados da década de 60, compondo os planos do governo militar vigente para uma integração do território nacional e instalação de uma rede nacional, investindo em termos de infraestrutura com micro-ondas e satélites (LOPES, 2002). Tal fenômeno denota a íntima relação entre a produção de bens culturais e o Estado, como distribuidor e regulador dessa produção, sobretudo no cenário político e social de repressão e censura após o golpe militar de 1964:

É a partir desse cenário político, econômico e cultural que a televisão foi e continua sendo decisiva na constituição do espaço público brasileiro. $\mathrm{O}$ acesso da grande maioria da população a outras formas culturais continua sendo muito limitado e resume-se, principalmente, à televisão, desse modo é inegável seu potencial mobilizador, educativo e cultural. A televisão convoca as pessoas de modo muito singular, como nenhum outro meio faz. Com largo alcance cultural ela se tornou o espaço estratégico de representação e de conexão entre os cidadãos, de seu pertencer a uma comunidade. (SILVA, 2013, p. 7).

Dessa maneira, pode-se considerar a televisão, ainda nos dias atuais, como principal elo social brasileiro, acessada tanto pelas classes populares quanto pelas elites, principal espaço, vitrine, e parâmetro de representação e reconhecimento dos sujeitos na composição de suas identidades, em clivagens como classe social, gênero e sexualidade, raça e etnia, faixa etária, etc., uma ponte entre o público e o acesso a outras formas culturais para a grande maioria de sua audiência, funcionando como um referencial de mundo, consolidando rituais e fixando pautas, logo, possui um grande potencial educativo porque impulsiona um sentimento de pertencimento a um grupo ou comunidade. 


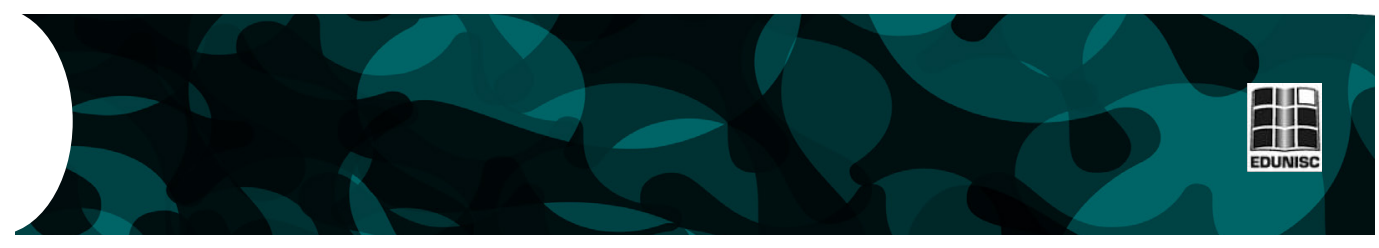

Podemos dizer que tais aspectos se devem ao fato de que a televisão, de um modo geral, possui a capacidade de penetração intensa na sociedade por meio de sua contribuição para um determinado "repertório comum" que se estabelece como a base de representações de uma nação idealizada ou comunidade nacional imaginada a qual este meio de comunicação consolida, reproduz e também atualiza, logo, longe de veicular significados consensuais, podemos dizer que a relação entre a televisão e sua audiência se faz sob uma luta constante pelos sentidos (LOPES, 2001; 2002).

A televisão brasileira tem a telenovela como seu principal produto, em um modelo de produção em massa, que desde o seu nascimento acolhe cânones ou elementos já estabilizados, bem como se diferencia em suas determinadas especificidades que o gênero ganha por aqui, sobretudo, no uso de uma tecnologia de ponta, e um desejo de cada vez mais ser interessante e chamar a atenção de sua audiência (SILVA, 2013).

A primeira telenovela brasileira, "Sua vida me pertence", foi veiculada pela TV Tupi em 1951, primeira emissora de televisão do país e quarta na América do Sul, fundada por Assis Chateaubriand em 1950. As primeiras telenovelas brasileiras eram encenadas ao vivo no teatro, apresentando uma estrutura de dramaturgia radiofônica, com um elenco artístico e técnico que vinha do rádio e das antecessoras radionovelas. Com capítulos semanais e enredos adaptados de radionovelas e originados das produções de países como Argentina, Cuba e México, apresentavam uma predominância da estética melodramática, com poucas personagens, entre principais e secundárias, e desenvolvimento superficial de suas características psicológicas (MARQUES; LOPES; LISBÔA FILHO, 2011).

Neste aspecto, é possível pensar os elementos básicos do melodrama como fios condutores da telenovela e alicerce para sua narrativa, vigorando como estrutura tanto no passado, na introdução do gênero no país, como nos dias atuais, elementos do melodrama ainda vigorantes. Assim, a telenovela atualmente ainda resguarda elementos melodramáticos nevrálgicos $\mathrm{e}$ significações fundamentais, sobretudo, a história de amor e o romance como tronco da narrativa e o conflito entre o bem e o mal, além, é claro, da mensagem moralizante e a alternância entre momentos dramáticos e cômicos.

Desse modo, pode-se dizer que a telenovela brasileira consegue conjugar em seu interior elementos melodramáticos já consagrados e de lugar-comum com temáticas nacionais do cotidiano dentro do seu tempo de veiculação na televisão, tendo o melodrama como matriz cultural principal. É por seu modo de estruturar e representar o cotidiano nacional e por seu constante diálogo vivo com os acontecimentos e tendências do presente, além de uma constante evolução de seu aparato tecnológico e audiovisual, impulsionada por um regime de verossimilhança e "naturalização" de suas histórias para atrair cada vez mais seu público, que a telenovela no país se consolida como produto genuinamente brasileiro (MOTTER, 2001), destacando-se das demais produções no exterior, sobretudo na América Latina, o que permite que hoje seja encarada como elemento central e objeto de credibilidade nos debates sobre cultura brasileira e identidade nacional (LOPES, 2002). 


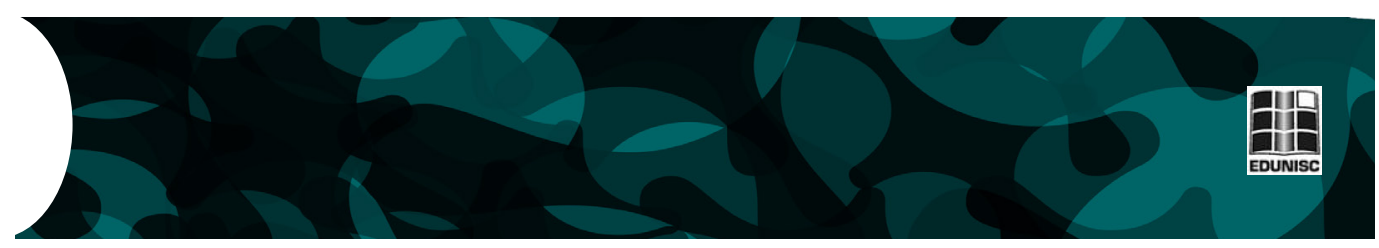

Podemos dizer que esse movimento que parte cada vez mais de uma ficcionalidade para uma "cotidianização" (MARQUES; LOPES; LISBÔA FILHO, 2011), se inicia nos fins dos anos 60 e início dos 70 , quando a telenovela se desenvencilha do caráter mais melodramático, uma vez que seguia até então o estilo latino-americano de "dramalhões" mais "fantasiosos" e distantes da realidade brasileira (personagens com nomes estrangeiros, diálogos formais, ambientação em lugares longínquos do território brasileiro) (SILVA, 2013; LOPES, 2002). Muda suas temáticas para enredos mais realistas do cotidiano brasileiro. "Deste modo, inicia um processo de aculturação na telenovela brasileira, pois os temas abordados estão imersos na própria sociedade. Inicia-se a exposição da diversidade cultural compreendida pelo próprio país" (MARQUES; LOPES; LISBÔA FILHO, 2011, p. 7).

Torna-se marco desse novo paradigma de "abrasileiramento" do gênero a telenovela "Beto Rockfeller" (TV Tupi, 1968) que trazia em seu enredo uma ambientação no universo contemporâneo das grandes cidades brasileiras, espaços de representação da modernidade no país, linguagem coloquial e humor, introduzindo gírias e expressões cotidianas, certa ambiguidade no caráter das personagens, com um protagonista "anti-herói", referências compartilhadas pelo público brasileiro, com representação de um público jovem recém-chegado às grandes metrópoles do país, remetendo a acontecimentos da vida e notícias da época; em um contexto de grande fluxo populacional do campo para as cidades, industrialização e desenvolvimento do mercado de consumo, sendo considerada a primeira telenovela a fazer merchandising, ainda que de maneira não-oficial.

Determinados padrões e receitas são adotados a partir daí, sendo convencionado que cada produção deveria apresentar "novidades", calcando-se sempre em uma representação de contemporaneidade e em consonância com o tempo de sua veiculação. Isso se demonstra em termos da moda, uso das tecnologias, consumo de produtos e remetendo aos acontecimentos da vida.

Sem nunca perder de vista a sua base, sua raiz cultural melodramática e, portanto, ainda ter como base a narrativa da família e da vida privada, paradoxalmente, a telenovela se fortalece como um potencial fórum de debates no espaço público, representando no âmbito doméstico desdobramentos de questões públicas e trazendo para a superfície do espaço público, problemáticas da vida privada.

Neste seguimento, podemos pensar em uma constante dinamicidade e relação dialógica que se trava entre a realidade e a telenovela, relação na qual a vida dá sentidos à ficção e a ficção dá sentidos aos acontecimentos da vida. Desse modo, podemos dizer que a telenovela responde de alguma maneira a questões que estão se dando no tecido social em seu momento de veiculação. Essa projeção de questões e pautas destacadas da vida, no entanto, pode e deve ser encarada em caráter de seleção de temáticas: "A novela dá visibilidade a certos assuntos, comportamentos, produtos e não a outros; ela define uma certa pauta que regula as interseções entre a vida pública e a vida privada" (LOPES, 2002, p. 3). As temáticas pautadas pela 
telenovela, e a própria obra como um todo, usufruem de grande credibilidade e legitimidade no que diz respeito a um certo imaginário de nação brasileira $\mathrm{e}$ são tidas como o próprio reflexo do cotidiano e da realidade nacional, e uma vez pautando questões que já podem estar circulando no espaço público e em outros meios de comunicação de massa, passa a ter seu valor de verdade perante a sociedade ainda mais potencializado:

Questões como a reforma agrária, o coronelismo (o poder das oligarquias locais), a especulação imobiliária, as companhias multinacionais, a corrupção política, o racismo, as minorias, entre outras, são alguns exemplos dessa vocação das novelas de incorporar temas do âmbito público em suas narrativas teoricamente voltadas para o universo privado. Mas temáticas como essas nas novelas são inseparáveis das temáticas do romance, da família, do amor, do casamento, da separação. É a lógica das relações pessoais, familiares que preside a narrativa dos problemas sociais. (LOPES, 2002, p. 13).

Assim, a vida pode dar o tom à narrativa da telenovela, ao mesmo tempo que a obra pode estimular a emergência de questões e assuntos a serem discutidos na vida, sendo uma instância importante de influência em debates públicos sobre questões políticas e sociais, polêmicas nacionais, por exemplo.

As instâncias de produção, exibição e recepção da telenovela acontecem quase em caráter de simultaneidade: a obra ficcional é escrita, gravada e produzida, e assistida ao mesmo tempo (SILVA, 2013). O público sente-se como participante da telenovela, rejeitando conteúdos, demandando mudanças, como pode ser observado quando tramas e histórias são mudadas a partir de reivindicações do telespectador, movimentos sociais e minorias políticas, sindicatos e grupos profissionais.

Pensando essa proposta e a ideia de relação dialógica entre vida e arte com Bakhtin [Volochínov] (2009), primeiramente podemos conceber a noção de diálogo em um sentido amplo, como um motor para todos os tipos de comunicação verbal. Nesse caso, qualquer que seja o tipo de comunicação produzida no interior de uma dada comunidade, a mesma parte do Eu para o Outro. A palavra serve de ponte e mediação nas relações entre sujeitos, logo, desde a conversa cotidiana, até a obra literária, bem como as produções culturais que conhecemos como o cinema, as telenovelas, as peças publicitárias, as notícias de jornais, a revista em quadrinhos, e até mesmo os trabalhos científicos, as leis e documentos oficiais, enfim, todos os tipos de comunicação verbal partem de um sujeito a outro sujeito. É um dos motivos pelo qual a estrutura da enunciação é sempre sociológica, uma vez que a mesma se molda de acordo com a nossa relação com o interlocutor (VOLOCHÍNOV, 2013). Portanto, um diálogo sempre compreende pelo menos dois participantes, um dos princípios pelos quais também sob um determinado signo ideológico ou palavra se confrontam valores diferentes.

Seguindo por essa constatação, temos condição para nos atentarmos para o caráter dialógico da enunciação. Bakhtin (2011) compreende o enunciado como "real unidade da comunicação discursiva" e ressalta o fato de que os mesmos comportam em si 

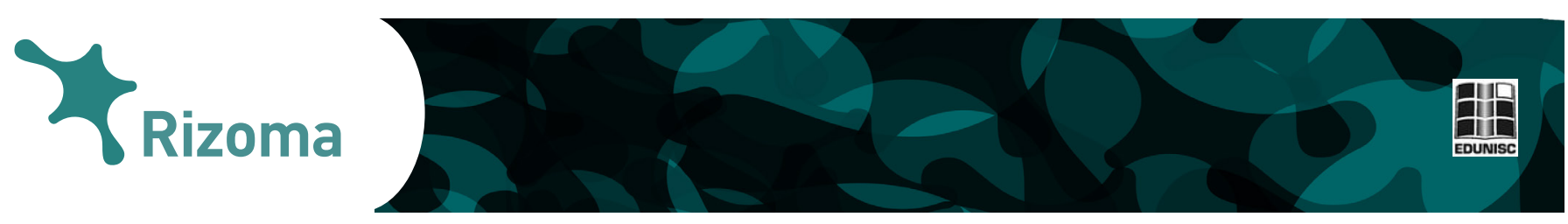

[...] ecos e ressonâncias de outros enunciados com os quais está ligado pela identidade da esfera de comunicação discursiva. Cada enunciado deve ser visto antes de tudo como uma resposta aos enunciados precedentes de um determinado campo (aqui concebemos a palavra "resposta" no sentido mais amplo): ela os rejeita, confirma, completa, baseia-se neles, subentende-os como conhecidos, de certo modo os leva em conta" (BAKHTIN, 2011, p. 297, grifos do autor).

Desta forma, todo enunciado, seja um gênero do discurso complexo ou simples, relaciona-se com outros enunciados produzidos antes dele, relacionando-se com vozes outras, com outros projetos de dizer. Eles vêm de outros sujeitos e suas diferentes posições ideológicas e lugares sociais, marcados ou não linguisticamente, apresentando diferentes graus dessa heterogeneidade constitutiva da comunicação discursiva (BAKHTIN, 2011).

\section{Lado a Lado: retrospectivas e prospectivas}

A telenovela "Lado a Lado" (Rede Globo, 2012) foi produzida e transmitida pela Rede Globo de Televisão no período entre setembro de 2012 e março de 2013. Foi veiculada dentro da programação como novela das seis, logo, exibida às $18 \mathrm{~h} 25$ de segunda a sábado, e teve como contexto para sua história a cidade do Rio de Janeiro, no início do século XX (com a primeira fase ambientada no ano de 1903 e a segunda no ano de 1910). Escrita por Cláudia Lage e João Ximenes Braga, a trama tinha como pano de fundo o período de recente abolição da escravidão e os primeiros anos da república, pela Lei Áurea em 1888 e a Proclamação da República em 1889, retratando as transformações sociais e políticas na capital do Brasil na época e alguns fatos históricos importantes da história do país.

Assim, a telenovela tinha como narrativa principal os conflitos e desencontros amorosos enfrentados pelos dois casais protagonistas (Isabel e Zé Maria; Laura e Edgar), ambos posicionando-se de alguma forma à frente de seu tempo. São retratadas suas lutas pela independência feminina, contra o machismo, o racismo, exclusão social dos negros e mais pobres, e na defesa das manifestações culturais afro-brasileiras.

Como um primeiro gesto de compreensão e retomando o que refletimos até aqui sobre a matriz cultural da telenovela, podemos encontrar em "Lado a Lado" (Rede Globo, 2012) alguns dos elementos básicos do melodrama: a história de amor como tronco da narrativa, no caso dos casais protagonistas, e um desfecho que se encaminha para a realização amorosa, resolução dos desencontros; as relações familiares como base para a história, os conflitos, além dos desdobramentos dos fatos históricos que se dão no âmbito e pela ótica dessas relações, tanto dentro das famílias ricas como das pobres. Além desses, podemos destacar ainda a oposição que se estabelece entre bem e mal, entre vilões e heróis, vícios e virtudes (a ex-baronesa racista e retrógrada, Constância; governantes e autoridades corruptas, como o senador Bonifácio; a vizinha de Isabel, Berenice, sentindo inveja da protagonista e tentando a todo 
custo separá-la de Zé Maria, por quem é apaixonada; Caniço, capoeirista maucaráter, que usa a capoeira para cometer crimes, cooperando para sua má fama e se tornando inimigo de Zé Maria; Catarina, ex-interesse amoroso de Edgar, tentando separá-lo de Laura; Fernando, irmão invejoso, preconceituoso e maucaráter de Edgar), demonstrando um enredo cheio de perseguições, intrigas, armadilhas, reviravoltas e vinganças, bem como uma mensagem moralizante. Ainda sobre a estrutura melodramática, temos o drama do reconhecimento no caso do filho de Isabel. A ex-baronesa Constância, no intuito de esconder da sociedade o neto negro, fruto do envolvimento de Isabel com Albertinho, arma um plano e forja a morte da criança com a ajuda de Berenice, doando o bebê. A criança é criada por Zenaide, irmã de Berenice e cresce sem saber quem são os verdadeiros pais, história descoberta por Isabel no desenrolar da novela. Podemos observar também uma alternância entre momentos sentimentais e de emoção (entre os casais, Isabel e seu pai), ação (cenas de luta da capoeira, revoltas populares) e comédia (o alívio cômico da novela fica por conta do núcleo de personagens do Teatro Alheira, uma companhia de teatro da cidade).

Outro conflito constante colocado em "Lado a Lado" (Rede Globo, 2012) é a oposição geracional, entre personagens com ideias mais progressistas, a maioria jovens, e personagens mais retrógrados, adeptos dos velhos costumes, saudosistas da velha ordem e organização social de outrora (monarquia, escravidão, submissão da mulher, etc.), contrapondo-se aos entusiastas do novo século e das mudanças sociais. Daí que o "novo século" e "novos tempos" são sempre retomados em enunciados e expressões como: "é o novo século"; "já estamos no século XX"; "novo mundo"; "[...] filhos que iam saber que os avós foram escravos [...] mas que a gente ia criar um mundo melhor pra eles [...] um mundo onde ia falar de escravidão apenas como lição para que nunca mais se repetisse"; "os tempos estão mudando".

Além dos elementos melodramáticos, "Lado a Lado" (Rede Globo, 2012) dá muito destaque aos fatos históricos mais importantes da época que retrata, que contam com a participação de suas personagens: instalação recente da República, demonstrando as novas relações entre povo e Estado no novo regime; as revoltas populares como a Revolta da Vacina e a Revolta da Chibata; o "Bota-Abaixo" na cidade do Rio de Janeiro do início do século XIX, processo de derrubada de cortiços, habitações de muitas famílias pobres (a maioria formada por ex-escravos, filhos de escravos, soldados, imigrantes) tidas como foco de doenças devido à falta de saneamento básico, como parte da urbanização e modernização, que contava ainda com a construção de avenidas, prédios com arquitetura europeia, chegada da energia elétrica nas ruas, expansão de linhas de bonde que visavam a aproximar a cidade de Paris, movimento que se chamou de Belle Époque (1871-1914); a Belle Époque ainda foi retratada nos costumes da elite, em termos de moda, estabelecimentos comerciais, consumo de produtos europeus, o tipo de dança e música legitimadas socialmente, os padrões de civilidade e sociabilidade, além das práticas higienistas que visavam à limpeza da cidade e o ideal de branqueamento com o enaltecimento da imigração europeia que se iniciava; a formação das primeiras favelas e periferias do Rio de Janeiro a partir da 
população negra e pobre expulsa dos cortiços do centro da cidade, como o Morro da Providência, no qual a família e amigos de Isabel vão morar após o "Bota-Abaixo"; proibição e criminalização da capoeira e os cultos ao candomblé, religião de matriz africana; estigmatização e surgimento do samba e do carnaval de rua, manifestações culturais associadas aos negros; a chegada do futebol no Brasil e o racismo, e a criação dos primeiros times de futebol carioca como o Botafogo e Fluminense; invenções como a fotografia, o cinematógrafo, primeiros automóveis circulando na cidade.

Desse modo, podemos considerar que ao mesmo tempo em que "Lado a Lado" (Rede Globo, 2012) constrói uma ficção de época, a obra também retoma fatos históricos específicos e verídicos. Logo, os acontecimentos reais são vistos dentro do âmbito das vidas de personagens ficcionais. Seguem abaixo exemplos de discursos e diálogos entre personagens da telenovela sobre corrupção, Brasil como país do futebol, cultura afro-brasileira entre outros:

\section{i) Corrupção}

Fernando: Eu sou filho de um corrupto.

Umberto: E isso lá é vergonha nesse país? (Rede Globo, Lado a Lado, 2012).

ii) Brasil como "país do futebol"

Fernando: [...] quem sabe no futuro o Brasil não se torne o país do football? (REDE GLOBO, Lado a Lado, 2012).

iii) Samba como patrimônio cultural brasileiro

Constância: [...] o tal do samba, imagine Celinha se essa batucada de africanos, de macumbeiros, algum dia vai ter qualquer importância para o Brasil? (Rede Globo, Lado a Lado, 2012).

iv) Ineficiência de serviços públicos

Bonifácio: [..] se eu não soubesse que esse país é desorganizado [...] (Rede Globo, Lado a Lado, 2012).

É interessante notar que a novela, ao recuperar os fatos históricos e representar a história do país, ressignifica esses acontecimentos, mobilizando uma memória coletiva e retomando alguns mitos, sobretudo, sobre a construção e formação da cultura brasileira. Apesar de ressignificar alguns acontecimentos de nossa história, também reafirma algumas representações e uma certa identidade brasileira ou ainda um modo de ser do brasileiro, estabelecendo alguns paralelos com o tempo presente.

Esse jogo entre passado e presente pode ser compreendido em algumas "projeções" que a obra faz do Brasil de 2012, mobilizando uma certa brasilidade e identidade nacional, bem como alguns costumes e vícios.

A retomada desses signos que caracterizam simbolicamente a identidade brasileira aproxima a telenovela do tempo presente, em que esses discursos circulam e reverberam sentidos. Muito embora, possamos dizer que ao mesmo tempo que retoma esses dizeres, ressignifica os mesmos, isso porque os contextualiza como constituinte do pensamento da sociedade brasileira do início do século XX.

Ainda sobre a relação de "Lado a Lado" (Rede Globo, 2012) com o presente e sua potencialidade de mobilizar questões atuais, podemos destacar a cena em que a protagonista Laura, após se divorciar de Edgar, por descobrir que 
o mesmo teve uma filha em Portugal, e carregar o estigma social de "mulher divorciada", sofre uma tentativa de abuso sexual do senador Laranjeira. Outro fator que pode demonstrar a relação da novela com o presente é a trilha sonora contemporânea utilizada, com músicas atuais, um modelo atípico em tramas de época, incluindo sambas atuais e um rap nacional, remetendo ao movimento hip hop como resistência da periferia, executados principalmente na ambientação dos espaços periféricos, como o Morro da Providência. Traz também elementos como diálogos coloquiais contemporâneos, sendo criticada inclusive sobre esta questão, especificamente em torno do uso da palavra "divórcio", ou expressões utilizadas pela personagem Neusinha como "Adoro!".

De fato, "Lado a Lado" coloca-se como a história dos avanços do presente, dos direitos adquiridos nos dias atuais, discurso presente nos anúncios da telenovela na televisão, que recupera imagens históricas tanto verídicas como fictícias de movimentos como o movimento "caras pintadas" de impeachment do presidente Fernando Collor, movimento hippie e de contracultura dos Estados Unidos, movimento de direitos civis dos negros nos Estados Unidos, a independência da mulher feminina e inserção das mulheres no mercado de trabalho, etc.

Escolhida pelo Emmy Internacional como "Melhor novela de 2013", "Lado a Lado" também foi premiada pelo Centro de Articulação de Populações Marginalizadas (CEAP) no mesmo ano, na sétima edição do Prêmio Camélia da Liberdade, vencendo na categoria "Veículo de Comunicação", por retratar as condições da população negra após a abolição da escravidão, trazendo reflexões sobre o tempo presente e a situação atual do negro no Brasil. É importante ressaltar que a telenovela traz também um primeiro casal protagonista negro, Camila Pitanga e Lázaro Ramos (Isabel e Zé Maria).

Outro fator que devemos destacar sobre a novela e o protagonismo negro no gênero é o fato de que a obra foi a que mais apresentou personagens não-brancos (31\%) em sua trama central nos últimos 20 anos $^{4}$.

Neste seguimento (segmento?), é importante pensar na representação dos negros na trama, assim como os problemas enfrentados por essa população, sobretudo no que se refere ao prejuízo histórico e ao racismo estrutural, pensando na época da história:

Zé Maria: Agora eu quero lembrar uma coisa pro senhor, a escravidão já acabou há 22 anos no Brasil, agora tem gente que não entendeu isso ainda, né? [...] Que disciplina é essa? Que só é aplicada aos marujos negros? [...] Que o meu corpo fique marcado pra eu mostrar pros filhos que eu ainda vou ter, assim como meu pai me mostrou as surras que ele levou na época em que era escravo [...] já são $\mathbf{4 0 0}$ anos de açoite no meu povo, capitão, e o senhor pode ter certeza, isso vai acabar, os meus filhos não vão ser açoitados como o pai e o avô, não. Eles vão viver num mundo diferente desse que vocês criaram, desse mundo de intolerância, de violência e de um ódio sem explicação (Rede Globo, Lado a Lado, 2012).

Afonso: [...] a gente achava que não tinha mais feitor e dono de escravo, mas eles tão tudo aí disfarçado de autoridade (Rede Globo, Lado a Lado, 2012).

Zé Maria: Quando a polícia e os jornais falam que a capoeira é coisa de bandido, é porque é coisa de preto, mas essa foi a única maneira que o nosso povo encontrou na época da escravidão pra poder se defender da violência dos
4 Dado retirado da pesquisa "A raça e o gênero nas novelas nos últimos 20 anos", realizada pelo Grupo de Estudos Multidisciplinares da Ação Afirmativa (GEMAA): Disponível em $<$ http://gemaa.iesp.uerj.br/infografico/infografico3/ > Acesso em maio de 2017. 


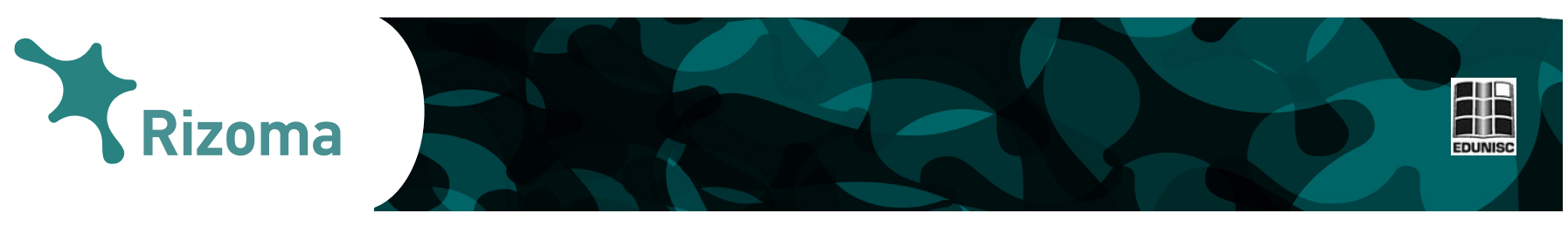

capitães do mato [...] a escravidão já acabou, mas ainda falta muito pra gente conquistar respeito, uma vida digna (Rede Globo, Lado a Lado, 2012). Zé Maria: A gente lutou muito até conquistar a nossa liberdade, mas ainda falta muito até a gente conseguir respeito [...] (Rede Globo, Lado a Lado, 2012).

Isabel: E eu quero muito crescer [...] o Brasil ainda vai demorar muito tempo pra apagar as manchas da escravidão, eu sei que aqui eu não tenho muita chance (Rede Globo, Lado a Lado, 2012).

Tia Jurema: um dia isso vai fazer toda diferença, o orgulho que você e seus companheiros deram pro Elias e pra toda essa garotada feito ele, de que não precisa baixar a cabeça porque é negro, precisa lutar [...] faz mais diferença do que o que o governo tem feito até agora [...] vai fazer diferença pro filho do Elias, pro neto dele [...] (Rede Globo, Lado a Lado, 2012).

\section{Considerações finais}

Tendo em conta a constatação de que o enunciado se encontra relacionado com a situação extraverbal mais ampla que the engatilha, podemos entender os discursos da telenovela na esteira das transformações ocorridas no ano de 2012, como a aprovação da política de Ações Afirmativas e cotas raciais para o Ensino Superior, consolidada pela Lei de Cotas, a partir do julgamento pelo STF pela constitucionalidade das inciativas de Ações Afirmativas. É na esteira de um longo processo histórico de emergência de um governo de posicionamento político de centro-esquerda, que se coloca mais próximo às reivindicações do movimento social negro, e alguns avanços como a aprovação do Estatuto da Igualdade Racial, criação da SEPPIR, etc., em que as demandas do movimento negro contra a ideia do mito da democracia racial começa a tomar as esferas do poder público e compor a agenda política do país, sobretudo no início dos anos 2000, com as primeiras iniciativas de Ações Afirmativas exercidas por algumas instituições de Ensino. Por tanto, podemos pensar esse tempo futuro como signo que comporta sentidos que podem estar relacionados tanto ao ano de 2012, na perspectiva da narrativa ambientada em 1910, quanto em uma prospectiva de um futuro ainda mais distante de 2012.

\section{Referências}

BAKHTIN, M. Estética da criação verbal. São Paulo: Editora Martins Fontes, 2011.

LOPES, Maria Immacolata Vassallo. Narrativas televisivas e identidade nacional: o caso da telenovela brasileira. In: XXV CONGRESSO ANUAL EM CIÊNCIA DA COMUNICAÇÃO, 2002, Salvador. Anais... Salvador: INTERCOM, 2002. Disponível em <http://www.intercom.org.br/papers/nacionais/2002/ Congresso2002_Anais/2002_NP14LOPES.pdf > Acesso em: maio 2017.

Telenovela Brasileira: Uma narrativa sobre a nação. Comunicação 

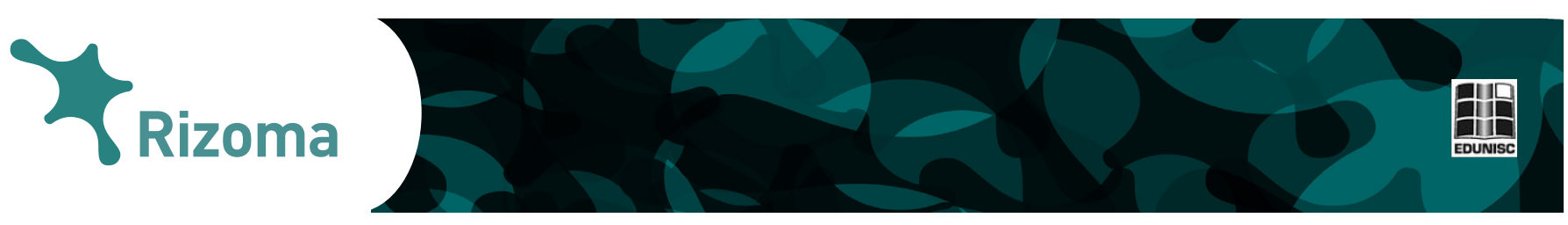

\& Educação, São Paulo, n. 26, p. 17-34, jan./abr. 2001.

MARQUES, D. P.; LOPES, I. G.; LISBÔA FILHO, F. F. Percursos e características da telenovela brasileira. In: VIII ENCONTRO NACIONAL DE HISTÓRIA DA MÍDIA, 2011, Guarapuava. Anais... Guarapuava: ALCAR, 2011. Disponível em <http://www.ufrgs.br/alcar/encontros-nacionais-1/8oencontro-20111/artigos/Percursos $\% 20 \mathrm{e} \% 20$ caracteristicas $\% 20 \mathrm{da} \% 20$ telenovela\%20brasileira.pdf/at_download/file > Acesso em: maio de 2017.

MARTÍN-BARBERO, Jesús. Dos meios às mediações: comunicação, cultura e hegemonia. Rio de Janeiro: Editora UFRJ, 2009.

MOTTER, Maria Lourdes. A telenovela: documento histórico e lugar de memória. Revista USP, São Paulo, n. 48, p. 74-87, 2001.

SILVA, Flávio Luiz Porto e. Melodrama, folhetim e telenovela: anotações para um estudo comparativo. FACOM, n. 15, p. 46-54, jul./dez. 2005.

SILVA, Lourdes. Melodrama e telenovela: dimensões histórica de um gênero/ formato. In: ENCONTRO NACIONAL DE HISTÓRIA DA MÍDIA, 2013, Ouro Preto. Anais... Ouro Preto: ALCAR, 2013. Disponível em $<$ http://www. ufrgs.br/alcar/encontros-nacionais-1/9o-encontro-2013/artigos/gt-historia-damidia-audiovisual-e-visual/melodrama-e-telenovela-dimensoes-historica-deum-genero-formato > Acesso em: maio de 2017.

VOLOCHÍNOV, Valentin Nikoláievitch [BAKHTIN, M.]. Marxismo e Filosofia da Linguagem. São Paulo: Editora Hucitec, 2009.

VOLOCHÍNOV, Valentin Nikoláievitch. A palavra na vida e a palavra na poesia: introdução ao problema da poética sociológica. In: . A construção da enunciação e outros ensaios. São Carlos: Pedro \& João Editores, 2013.

\section{Outras fontes consultadas}

LADO A LADO. Rede Globo de Televisão. Autores: João Ximenes Braga e Claudia Lage. Direção: Dennis Carvalho e Vinícius Coimbra. 154 capítulos, 50 minutos, 2012.

GRUPO DE ESTUDOS MULTIDISCIPLINARES DA AÇÃO AFIRMATIVA (GEMAA). Disponível em <http://gemaa.iesp.uerj.br/> Acesso em: maio de 2017. 